糖尿病発症のかぎを握るアディポネクチンの 受容体機能を解明!

\title{
門脇 孝
}

食生活の欧米化が進むなか、日本の糖尿病患者・予備群合わせた数は、1620万人にも達するといわれる。患者の多 くは、肥満や遺伝的な素因が複雑に関与する 2 型糖尿病。門脇孝教授は、東京大学大学院医学研究科糖尿病・代謝内 科において臨床に携わる一方で、肥満と糖尿病発症の関連についての研究を進めている。今回、そのかぎを握るアディ ポネクチンの受容体だと思われる 2 種のタンパク質を同定し、それらが確かに機能していることを明らかにした。こ の成果はNature Medicine2007年3月号で発表された。

\begin{abstract}
インスリン抵抗性との関連に着目
Nature Digest —なぜアディポネクチンに注目されたのでしょうか? 門脇 一私は東大病院で糖尿病・代謝内科の医師として臨床を 続け、一方で、糖尿病の原因究明を目標に研究も行ってきまし た。糖尿病は、日本でも世界でも増える一方ですが、その背景 には肥満の増加があります。2000年ごろには、肥満に伴って アディポネクチンの分泌量が減るという疫学的データが出てい ました。一方、そのころの私は、インスリン抵抗性*1 ${ }^{*}$ 改善薬の ターゲットでもあるPPAR y という因子に興味をもち、PPAR Y のへテロ欠損マウスを作って解析を進めていました。このマウ スはインスリン感受性が充進しており、私たちはPPAR yが工 ネルギー消費を向上させるレプチンというタンパク質の遺伝子 を転写レベルで抑制していることを突き止めました。さらに、 野生型マウスとPPAR $y$ ヘテロ欠損マウスの脂肪細胞内で発現 している遺伝子をDNAチップによって網羅的に比べてみたと ころ、PPARYへテロ欠損マウスで発現がえ進している遺伝子 があり、その中の 1 つがアディポネクチンの遺伝子であること がわかりました。こうしてアディポネクチンの上昇がインスリ
\end{abstract}

\section{アディポネクチン仮説}

遺伝素因

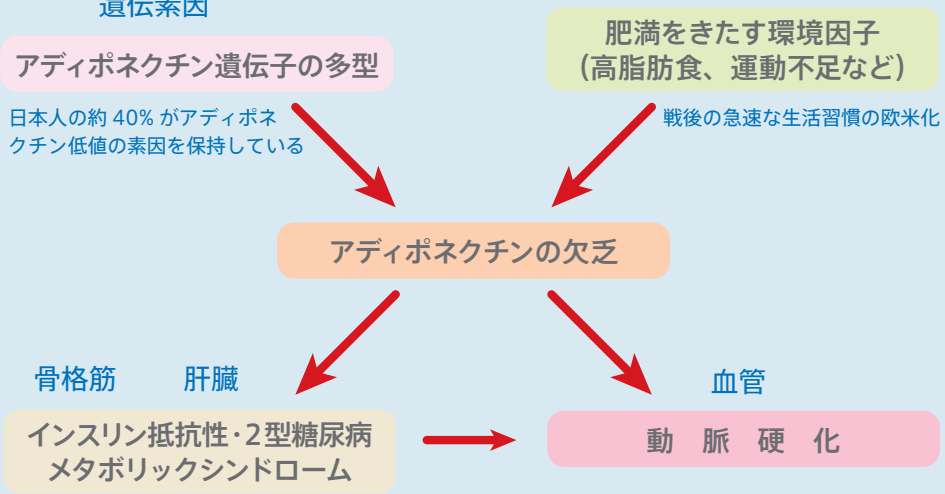

遺伝的な素因と肥満をきたす環境因子が相互作用することで、アディポネクチンの低下が引き起 こされ、インスリン抵抗性・2型糖尿病、メタボリックシンドロームの主要な原因になるとともに、 動脈硬化の直接的な原因となる。
ン感受性の充進と同時並行しておきていることを認識し、研究 室で力を入れて研究するようになりました。

ND 一アディポネクチンとはどのような物質ですか?

門脇 一脂肪細胞からは「アディポカイン」と総称されるさま ざまなホルモンやサイトカインが産生されていますが、アディ ポネクチンもその一種です。脂肪細胞から常に分泌されていま すが、空腹時に分泌量が増え、食事をすると減って、次の空腹 時に向けて再び増える傾向にあります。歴史的には、10年ほど 前にアディポネクチン同定の論文が4つ発表されました。ただし、 この時点ではどのような機能なのかは不明で、2001年の私た ちの研究によって、肥満かつメタボリック症候群の病態を示す マウスでアディポネクチンの分泌量が減っており、アディポネク チンを遺伝子組み換え技術を用いて補給してやると、インスリ ン抵抗性が回復して病態も改善することがわかりました ${ }^{1}$ 。同 じころ、アメリカの $2 つ$ 研究室からも独立に同様の成果を示 した論文が出され、アディポネクチンがインスリン抵抗性を改 善することで血糖值を下げる作用をもつ、糖代謝に極めて重要 なホルモンであると認知されるようになりました。 ND 一 どのような分子メカニズムで血糖值を下げるのですか？ 門脇 一私たちはまず、脂肪細胞からアディポネクチンが分泌 されると、肝臓と筋肉において 2 つ情報伝達経路が活性化さ れることを明らかにしました ${ }^{2}$ その1つは、細胞がストレスに さらされるなどしてエネルギーが枯渴するようなときに、糖や 脂肪を取り込んでATPを産生する「AMPキナーゼ系」で、も う1つは、肝臓や筋肉中の「脂肪の燃焼に関わる酵素の遺伝子」 を調節している核内受容体（PPAR $\alpha)$ を活性化する系です。 これらの系が活性化されると、筋肉と肝臓において脂肪の燃焼 が促進され、肝臟においては糖の新生が抑えられるようになり ます。結果として、糖代謝が促進され、血糖值を下げる機能を 発揮するというわけです。また、患者さんとその兄弟 224 組 に協力いただき、「アディポネクチン遺伝子のなかに一塩基多型 (SNPS) があり、その部位がGG型の場合、GT型に比べて分泌 量が3分の 2 に低下し、糖尿病に2 倍なりやすくなること」も 突き止めました。さらに、日本人の実に40\%は、体質的にアディ

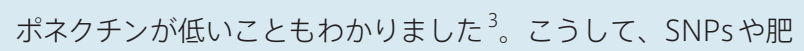




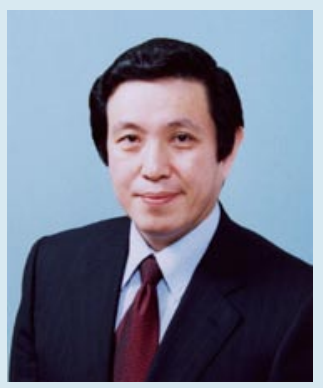

門脇 孝 (かどわき・たかし) /東京大学大学院 医学系研究科糖尿病・代謝内科教授。医学博士。 1978年東京大学医学部卒業。東京大学医学部附 属病院などにて内科研修。東京大学第 3 内科糖 尿病グループに所属。1986年から 1990 年まで 米国国立衛生研究所 $(\mathrm{NIH})$ 糖尿病部門に留学。 2003 年より現職。医学部附属病院副院長を兼任。

東京大学第 3 内科糖尿病グループにて春日雅人教 授 (現神戸大学大学院医学系研究科糖尿病・消化 器・腎臓内科教授、医学部附属病院長) に師事。
インスリンシグナル伝達の研究を始める。留学中 に、インスリン受容体遺伝子異常による糖尿病を 同定。帰国後、発生工学的手法を用いたインスリ ン作用・インスリン分泌・2型糖尿病の分子機構 研究を進め、1990年代の後半から脂肪細胞、特 にPPAR Yやアディポネクチンに関する研究を開 始。2001年、アディポネクチンのインスリン感受 性亢進作用を発見、2003 年アディポネクチン受 容体を同定。現在、糖尿病・メタボリックシンドロー ムの成因に関する基礎研究と診断法・治療法開発 のトランスレーショナル・リサーチを進めている。
満によって分泌量が低下すると、インスリン抵抗性と関連する 疾患（メタボリックシンドローム、糖尿病など）や、心筋梗塞な どの動脈硬化性の疾患、脂肪肝炎が発症しやすくなるのです (ア ディポクチンには抗炎症効果もあることがわかってきた)。さら に、アディポネクチンががん細胞のアポトーシスを促進させる機 能をもつこともわかり、肥満や糖尿病患者に肝臓がん、子宮体 がん、乳がん、大腸がんが多い理由にアディポネクチンの減少 が関与していると考えられるようになっています。

\section{カ業での解析が功を奏することに}

ND —アディポネクチンの受容体については、どのように研究 を進められたのでしょうか?

門脇一私たちはアディポネクチンを蛍光標識し、アディポネク チン受容体を発現する細胞をFACS とよばれる手法を用いて単 離しようと試みました。アディポネクチンはさまざまな受容体 と非特異的に結合してしまうので試行錯誤しましたが、結合が 特異的なものだけを拾う工夫をし、幸いにも、世界で初めて 2 種の受容体を同定することができました。その解析の結果、ア ディポネクチン受容体タンパク質は「細胞膜に7回貫通してい るタイプの受容体で、Gタンパク質共役型受容体 ${ }^{* 2}$ とよく似て いるが、細胞膜中のタンパク質の向きが、それまでに知られて いたGタンパク質とはまったく逆の新規の受容体ファミリーで ある」ということがわかりました。そのため、多数存在する G タンパク質を念頭にハイスループットで探索していた世界中の 研究者はアディポネクチン受容体を見つけ出すことができず、 力業で解析を進めていた私たちが、世界で初めて受容体を同定 する幸運を手にしたのです ${ }^{4}$ 。

ND 一具体的に、どのような受容体だったのでしょう？

門脇一 結合がどう変化するか、また、PPAR $\alpha$ の活性がどう変化する かを検討したところ、「2種のアディポネクチン受容体のうちの 1 つ（1型受容体）は短いタイプのアディポネクチンと強く結合し、 かつ、長いタイプのアディポネクチンとも結合すること」「もう $1 つ$ (2型受容体) は長いタイプのアディポネクチンと結合する こと」がわかりました。結合後は、アディポネクチンのシグナル が細胞内に伝わり、AMPキナーゼやPPAR $\alpha$ の系を活性化して いました。また、同定した受容体タンパク質か確かにアディポネ クチン受容体として機能していることを示すために、2種の受容 体の遺伝子がともに欠損しているダブルノックアウトマウスを作
製し、このようなマウスではアディポネクチンが細胞に結合せず、 機能を果たせないことも示しました ${ }^{5}$ 。

ND 一 今回の成果は、医療にどのように応用可能でしょうか? 門脇 一アディポネクチンは進化的に古く保存されているタンパ ク質で、植物にも似た構造と機能をもつペプチド（オスモチン） が存在することがわかってきています。私たちは、オスモチンが アディポネクチン受容体に結合することで、アディポネクチンと 同様・同レベルの機能を発揮することを突き止めており、JSTの プロジェクトとして、野菜や果物に含まれる「アディポネクチン 受容体のアゴニスト」や「アディポネクチン受容体の数を増やす 因子」を網羅的に探索しつつあります。実際に見つかれば、野 菜や果物、あるいはそこから抽出した成分を摂取することで糖 尿病を抑えられる可能性が出てくるでしょう。一方で私たちは、 アディポネクチンが脳脊髄液中にも存在し、食欲を増進する作用 をもつことも明らかにしつつあります。おそらく、アディポネク チンは人類が長い間さらされた飢餓時代に対応するホルモンだっ たのでしょう。中枢では食欲を増進させて脂肪を蓄積するよう にはたらき、末梢では脂肪を燃焼させて当座の飢餓を回避して いると思われます。創薬という点では、末梢においてアゴニスト を抗糖尿病薬として使い、中枢ではアンタゴニストを抗肥満薬と して使うことが理想ですが、使い分けができるようになるかど うかがかぎだといえるでしょう。私自身は、臨床の医師ならでの スタンスをもちつつ基礎研究も続けることで、アディポネクチン の生理的機能や構造、病態における影響、シグナル伝達の全貌 を解明したいと考えています。そのうえで、治療や創薬に結び つくような研究ができるとよいと思っています。

ND 一ありがとうございました。

聞き手は西村尚子 (サイエンスライター)。

*1 インスリン抵抗性

同じ量のインスリンが分泌されているにもかかわらず、その機能が発揮されに くく、正常な場合よりも血糖值が下がりにくくなる状態で、糖尿病の本態の1 つとされる。逆に、インスリンが効き過ぎる状態のことを「インスリン感受性 が立進」と表現する。

*2 Gタンパク質共役型受容体

細胞膜に7回貫通し、C末端が細胞内に向いている受容体の総称。リガンドと結 合することで、膜電位の変化、細胞内へのカルシウムイオンの流入や各種シグ ナルの伝達などを引き起こすことが知られている。

1. Yamauchi T. et al, Nature Medicine 7,941-946(2001)

2. Yamauchi T. et al, Nature Medicine 8, 1288-1295(2002)

3. Hara K. et al, Diabetes 51, 536-540(2002)

4. Yamauchi T. et al, Nature 423,762-769(2003)

5. Yamauchi T. et al, Nature Medicine 13-3,332-339(2007) 